\title{
ALKYL 1,1-DIALKOXY-ALKANE- and -ARENE-CARBOXYLATES. PART IV* 1-Alkoxyalkyl carboxylates
}

BY

\author{
J. W. SCHEEREN and R. J. F. NIVARD
}

(Department of Organic Chemistry, R. C. University, Nijmegen, The Netherlands).

\begin{abstract}
Aldehydes can be converted into I-alkoxyalkyl carboxylates under mild conditions by reaction with dialkoxymethyl carboxylates in the presence of carboxylic acids. A mechanism has been proposed to explain the appearance of orthoformate during the reaction, and the accelerating effect of this compound on the formation of 1-alkoxyalkyl carboxylates.

Thermostable 1-alkoxyalkyl carboxylates can be prepared also from acetals and carboxylic acids though in low yields.

Higher homologues were obtained from the 1-alkoxyalkyl acetates by exchange of the acid group in a distillation procedure. In a similar way formates were obtained from butyrates and the formic acid/triethylammonium formate azeotrope.
\end{abstract}

\section{1-Alkoxyalkyl carboxylates from aldehydes and dialkoxymethyl carboxylates}

\section{Introduction}

Continuing our investigations on the acid-catalysed decomposition of compounds, $\mathrm{RR}^{1} \mathrm{CXOCH}\left(\mathrm{OR}^{2}\right)\left(\mathrm{X}=\right.$ alkoxy or cyanide $\left.{ }^{1}\right)$, we studied this reaction for $\mathrm{X}=\mathrm{OAc}$. The compounds concerned, $\mathrm{RR}^{1} \mathrm{C}\left(\mathrm{OCOCH}_{3}\right)$ $\mathrm{OCH}\left(\mathrm{OR}^{2}\right)_{2}\left(\mathrm{R}^{1}=\mathrm{H}, \mathrm{R}^{2}=\mathrm{Me}\right.$ or $\left.\mathrm{Et}\right)$ (I) could be simply prepared from dialkoxymethyl acetates ${ }^{2}\left[\mathrm{HC}\left(\mathrm{OR}^{2}\right)_{2} \mathrm{OCOCH}_{3}\right]$ and aldehydes.

From NMR-measurements it appeared that on addition of acetic acid I decomposes relatively quickly, to the extent of about $75 \%$, into its starting compounds (aldehyde and dialkozymethyl acetate); the same mixture was obtained from equimolar amounts of aldehyde, dialkoxymethyl acetate and acetic acid.

When the acidic mixture was left for a longer time $(24 \mathrm{~h})$ the primary compounds disappeared completely and a l-alkoxyalkyl acetate $\mathrm{RCH}\left(\mathrm{OR}^{2}\right) \mathrm{OCOCH}_{3}$, together with some acetal, acylal RCH $\left(\mathrm{OCOCH}_{3}\right)_{2}$,

\footnotetext{
* Part III.J.W. Scheeren and W. Stevens, Rec. Trav. Chim. 88, 897, (1969).

** Part of this work is taken from $J . W$. Scheeren, Thesis, Leiden, 1967.

1 J.W. Scheeren, J. E. W. van Melick and R.J. F. Nivard, Chem. Comm. 1969, 1175.

2 J. W. Scheeren, A. P. M. van der Veek and W. Stevens, Rec. Trav. Chim. 88, 195 (1969).
} 
and $\left[\mathrm{CH}_{3} \mathrm{CH}\left(\mathrm{OCOCH}_{3}\right)\right]_{2} \mathrm{O}$ were formed. Variation of the aldehyde, acid or dialkoxymethyl carboxylates used, revealed that the reaction [1]

$$
\mathrm{RCHO}+\mathrm{HC}\left(\mathrm{OR}^{2}\right)_{2} \mathrm{OCOR}^{1} \stackrel{\mathrm{R}^{1} \mathrm{CONH}}{\longrightarrow} \mathrm{RCH}\left(\mathrm{OR}^{2}\right) \mathrm{OCOR}^{1}+\mathrm{HCOOR}^{2} \text { [1] }
$$

can be used as a general procedure for the synthesis of 1-alkoxyalkyl carboxylates in yields of $40-70 \%$.

Compared with other methods ${ }^{3,4,5}$ we have used a simpler starting material (aldehyde), a lower reaction temperature (mostly room temperature) and weaker acids as catalysts, which gives the procedure a much wider scope (Table II); the hitherto unknown and relatively unstable 1-alkoxyalkyl formates can also be obtained. Only with benzaldehyde was the conversion very slow; here we found a better procedure starting with benzaldehyde acetal and a dialkoxymethyl carboxylate (see further). Ketones did not react at all. Their acetals also failed to give 1-alkoxyalkyl carboxylates, because in these cases the products are unstable.

\section{Reaction mechanism}

a. Synthesis of compound I can be envisaged as an addition of the dialkoxymethyl carboxylate to the carbonyl function of the aldehyde [2] or as an addition of acetic acid followed by reaction with the dialkoxymethyl carboxylate [3] according to:

$$
\mathrm{RCHO}+\mathrm{CH}_{3} \mathrm{COOH} \rightleftarrows \mathrm{RCH}\left(\mathrm{OCOCH}_{3}\right) \mathrm{OH}
$$

$$
\begin{array}{r}
\left.\mathrm{RCH}\left(\mathrm{OCOCH}_{3}\right) \mathrm{OH}+\mathrm{HC}^{2} \mathrm{OR}^{2}\right) \mathrm{OCOCH}_{3} \rightleftarrows \\
\mathrm{RCH}\left(\mathrm{OCOCH}_{3}\right) \mathrm{OCH}\left(\mathrm{OR}^{2}\right)_{2}+\mathrm{CH}_{3} \mathrm{COOH}
\end{array}
$$

The unfavourable equilibrium in the first step of this scheme should be balanced by the high reactivity of dialkoxymethyl carboxylates towards all kinds of alcohols ${ }^{6}$ (second step).

On account of this high reactivity, reaction of dialkoxymethyl carboxylates with the enol form of the aldehyde used cannot be excluded.

However, because pivalic aldehyde which cannot enolise, also gives a compound I such a pathway cannot be general.

"Houben-Weyl, "Methoden der organischen Chemie", Georg Thieme Verlag, Stuttgart, 1965 , Band VI/3, p. 286, and references cited therein.

${ }^{4}$ C. D. Hurd and F. O. Green, J. Am. Chem. Soc. 63, 2201 (1941).

5 S. O. Lawesson, C. Berglund and S. Grönwall, Acta Chem. Scand. 15, 249 (1961).

${ }^{6}$ J.W. Scheeren and W. Stevens, Rec. Trav. Chim. 88, 897 (1969). 
As no intermediate could be detected in reaction mixtures of aldehydes and dialkoxymethyl carboxylates our experiments do not allow us to decide between the possibilities offered for the formation of the addition product $\mathbf{I}$.

b. Although the acid-catalysed formation of 1-alkoxyalkyl carboxylates from aldehydes and dialkoxymethyl carboxylates formally resembles acetal formation from aldehydes and orthoformates ${ }^{1}$, the mechanism must be more complex.

From NMR-measurements (Fig. 1) it is clear that the acid-catalysed equilibrium between acetaldehyde and diethoxymethyl acetate on one side and the addition product $\mathrm{CH}_{3} \mathrm{CH}\left(\mathrm{OCOCH}_{3}\right) \mathrm{OCH}\left(\mathrm{OC}_{2} \mathrm{H}_{5}\right)_{2}$ on the other is fast in comparison with the formation of the end product 1ethoxyethyl acetate.

In the presence of an equivalent amount of acetic acid, equilibrium is reached in 20 minutes; the surface of the $\mathrm{H}_{\mathrm{a}}$-peak is about three times that of $\mathbf{H}_{\mathrm{b}}$ or $\mathbf{H}_{\mathrm{c}}$. At that moment the amount of the end product appears to be very low (no $\mathrm{H}_{\mathrm{d}}$ absorption present). After 90 minutes the presence of 1-ethoxyethyl acetate $\left(\mathrm{H}_{\mathrm{d}}\right)$ becomes apparent; its formation is complete after $24 \mathrm{~h}$. At that moment small peaks of the side products $\mathrm{H}_{\mathrm{e}}$ : acetal, $\mathrm{H}_{\mathrm{f}}$ : $\left[\mathrm{CH}_{3} \mathrm{CH}\left(\mathrm{OCOCH}_{3}\right)\right]_{2} \mathrm{O}$, and $\mathrm{H}_{\mathrm{g}}$ : acylal can be observed ${ }^{7}$.

From these data, it is difficult to establish whether in the presence of acetic acid, the end product arises from aldehyde and diethoxymethyl acetate (Scheme 1, $a$ ), from the addition product $(b)$ or from all three components in the equilibrium mixtures $(c)$.

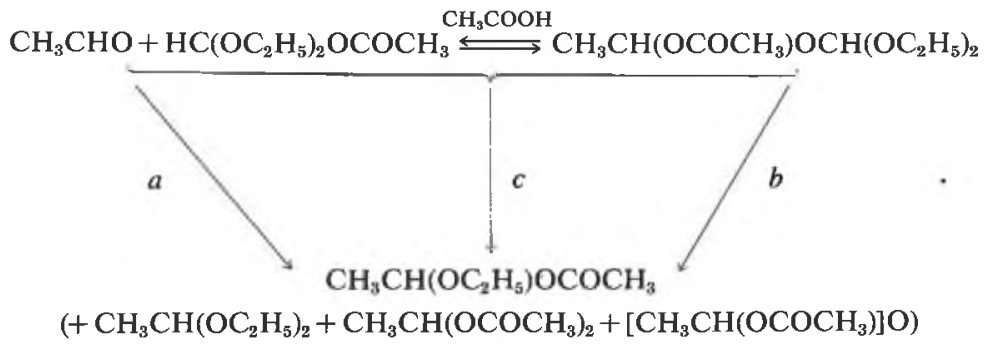

Scheme 1. Possible pathways for the formation of 1-alkoxyalkyl carboxylates

Careful inspection of the NMR spectra reveals that during the transformations in the reaction mixture ethyl orthoformate is formed. Its presence $\left[\mathrm{HC}(-\mathrm{O}-)_{3}\right.$ proton: 5.1 , singlet $]$ is clearly detectable after 90 min., but it vanished in the later phase of the reaction. A possible role of the orthoformate in the formation of the end product was confirmed by the explicit addition of orthoformate to the reaction mixture. In all

${ }^{7}$ See: J. W. Scheeren, Thesis, Leiden, 1967. 

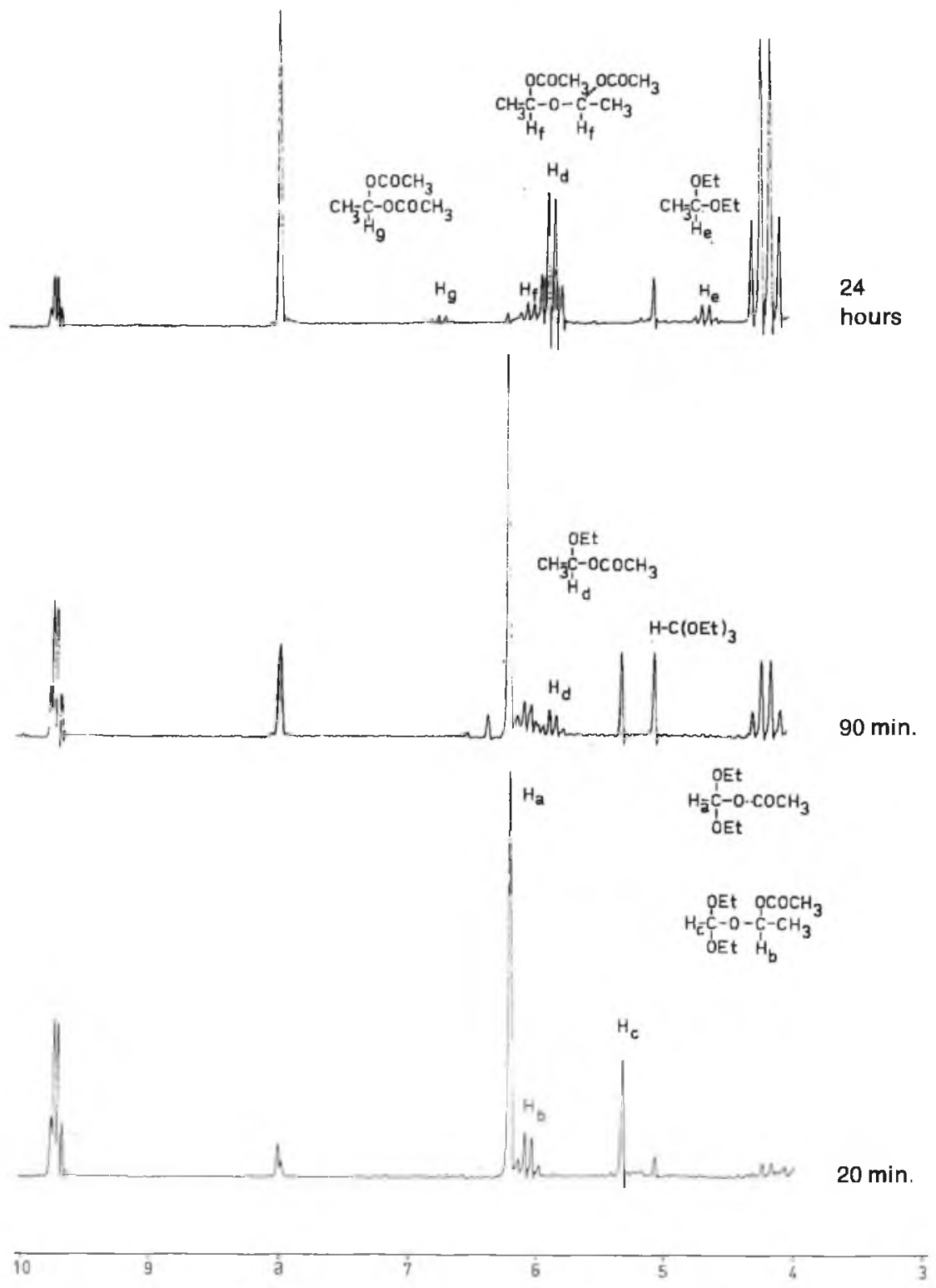

Fig. I. NMR spectra of the reaction mixtures of equimolar amounts of diethoxymethyl acetate, acetaldehyde and acetic acid, respectively $20 \mathrm{~min} ., 90 \mathrm{~min}$. and $24 \mathrm{~h}$ after mixing the components. 


\section{Table I}

Acceleration of the formation of 1-alkoxyethyl acetate by purposeful raising of the concentration of alkyl orthoformate. Dialkoxymethyl acetate, aldehyde and acetic acid are used in equimolar amounts.

\begin{tabular}{|c|c|c|c|}
\hline System & $\begin{array}{l}\text { Reaction } \\
\text { time }\end{array}$ & $\begin{array}{l}\text { Orthoformate relative to } \\
\text { the amount of dialkoxy- } \\
\text { methyl acetate added }\end{array}$ & $\begin{array}{c}\text { Yield of } \\
\text { 1-alkoxyethyl } \\
\text { acetate }\end{array}$ \\
\hline $\begin{array}{l}\text { dimethoxymethyl acetate } \\
\text { acetaldehyde } \\
\text { acetic acid } \\
\text { dimethoxymethyl acetate } \\
\text { acetaldehyde } \\
\text { acetic acid } \\
10 \% \text { methyl orthoformate } \\
\text { diethoxymethyl acetate } \\
\text { butyraldehyde } \\
\text { acetic acid } \\
\text { diethoxymethyl acetate } \\
\text { butyraldehyde } \\
\text { acetic acid } \\
10 \% \text { ethylorthoformate }\end{array}$ & $\begin{array}{l}20 \mathrm{~min} \\
48 \mathrm{~h} \\
20 \mathrm{~min} \\
48 \mathrm{~h} \\
20 \mathrm{~min} \\
120 \mathrm{~min} \\
20 \mathrm{~min} \\
120 \mathrm{~min}\end{array}$ & $\begin{array}{r}4 \% \\
15 \% \\
11 \% \\
22 \% \\
6 \% \\
11 \% \\
11 \% \\
16.5 \%\end{array}$ & $\begin{array}{l}\text { undetectable } \\
\qquad 28 \% \\
\text { undetectable } \\
40 \% \\
\text { undetectable } \\
11 \% \\
\text { undetectable } \\
18 \%\end{array}$ \\
\hline
\end{tabular}

such experiments an acceleration was observed. Two representative experiments are presented in Table I.

An explanation of these results seems possible, if the formation of 1alkoxyalkyl carboxylates in the presence of acetic acid proceeds via hemi-acetals in a way comparable with acetalisation in alcoholic medium (reactions [5] and [6]). Irreversible binding of water by carboxonium ions $\left(\mathrm{R}^{2} \mathrm{O}=\mathrm{CH}=\mathrm{OR}^{2}\right)^{+}$from dialkoxymethyl carboxylate (or orth $\rho^{-}$ formate) is essential for completion of the conversion (reaction [7]). Orthoformate is necessary to reach a critical concentration of alcohol in the medium (reaction [4]).

$$
\begin{aligned}
\mathrm{HC}\left(\mathrm{OR}^{2}\right)_{3}+\mathrm{R}^{1} \mathrm{COOH} & \rightleftarrows \mathrm{HC}\left(\mathrm{OR}^{2}\right)_{2} \mathrm{OCOR}^{1}+\mathrm{R}^{2} \mathrm{OH} \\
\mathrm{RCHO}+\mathrm{R}^{2} \mathrm{OH} & \rightleftarrows \mathrm{RCH}\left(\mathrm{OR}^{2}\right) \mathrm{OH} \\
\mathrm{RCH}\left(\mathrm{OR}^{2}\right) \mathrm{OH}+\mathrm{R}^{1} \mathrm{COOH} & \rightleftarrows \mathrm{RCH}\left(\mathrm{OR}^{2}\right) \mathrm{OCOR}^{1}+\mathrm{H}_{2} \mathrm{O} \\
\mathrm{HC}\left(\mathrm{OR}^{2}\right)_{2} \mathrm{OCOR} \mathrm{OCO}^{1}+\mathrm{H}_{2} \mathrm{O} & \rightarrow \mathrm{R}^{1} \mathrm{COOH}+\mathrm{HC}\left(\mathrm{OR}^{2}\right)_{2} \mathrm{OH} \\
& \rightarrow \mathrm{R}^{2} \mathrm{OH}+\mathrm{HCOOR}^{2}
\end{aligned}
$$

c. Careful inspection of the NMR spectra of the reaction mixtures showed that the side product $\left(\mathrm{RCHOCOR}^{1}\right)_{2} \mathrm{O}$, which is clearly visible in the NMR spectrum of the reaction mixture after $24 \mathrm{~h}\left(\mathrm{H}_{\mathrm{f}}\right.$ proton), appears very rapidly. Its amount grows steadily with the increasing 
amount of orthoformate. The formation of this product* can be stoichiometrically formulated as:

$$
\mathrm{RCHO}+\mathrm{R}^{1} \mathrm{COOH} \rightleftarrows\left(\mathrm{RCHOCOR}{ }^{1}\right)_{2} \mathrm{O}+\mathrm{H}_{2} \mathrm{O}
$$

The water from [8] reacts with dialkoxymethyl carboxylate [7] to form carboxylic acid, alkyl formate and alcohol. The presence of alcohol will give rise to orthoformate via equilibrium [4].

To some extent the presence of orthoformate in the reaction mixture may also be ascribed to disproportionation ${ }^{7}$ of the addition product $\mathrm{I}$ in the equilibrium mixture (reaction [9], $\mathrm{X}=\mathrm{OCOCH}_{3}$ ). A similar reaction has been found for $\mathrm{X}=\mathrm{CN}^{1}$.

$$
\text { ,2RCHXOCH}\left(\mathrm{OR}^{2}\right)_{2} \stackrel{\mathrm{H}^{+}}{\rightleftarrows}(\mathrm{RCHXO})_{2} \mathrm{CHOR}^{2}+\mathrm{HC}\left(\mathrm{OR}^{2}\right)_{3}
$$

Finally, the formation of acylals could be explained by a reaction according to:

$$
(\mathrm{RCHXO})_{2} \mathrm{CHOR}^{2} \rightarrow \mathrm{RCHO}+\mathrm{RCHX}_{2}+\mathrm{HCOOR}^{2}
$$

It seems very improbable that the formation of acylals will be analogous to that of 1-alkoxyalkyl carboxylates. The conversion of the intermediate $\mathrm{RCH}(\mathrm{OH}) \mathrm{OCOR}^{\mathbf{1}}$ with acetic acid should be a very slow reaction consequent upon the instability of the carboxonium ion [RCH-OCOR $\left.{ }^{1}\right]^{+}$. In accordance with this supposition no trace of acylal is found when 1-alkoxyalkyl carboxylates are mixed with an excess of acetic acid for $48 \mathrm{~h}$.

\section{Other synthetic procedures}

a. Several 1-alkoxyalkyl carboxylates could be prepared from acetals and carboxylic acids [11], removing the alcohol by distillation.

$$
\mathrm{RCH}\left(\mathrm{OR}^{2}\right)_{2}+\mathrm{R}^{1} \mathrm{COOH} \rightleftarrows \mathrm{RCH}\left(\mathrm{OR}^{2}\right) \mathrm{OCOR}^{1}+\mathrm{R}^{2} \mathrm{OH}
$$

Generally, however, the yields were low, not only because complete removal of the alcohol is difficult but also because of thermal (and acidcatalysed) decomposition of the product into aldehyde and ester. The decomposition rate increases over the range $\mathrm{R}^{2}=\mathrm{Me}<\mathrm{Et}<t$. But as found for dialkoxymethyl carboxylates ${ }^{2}$ and over the range $R^{1}=$ $\mathrm{Et}<\mathrm{Me}<\mathrm{H}$. Thus 1-ethoxyalkyl formates could not be obtained by this method.

b. Better results were obtained when a dialkoxymethyl carboxylate was added to remove the alcohol formed. $\alpha$-Alkoxybenzyl carboxylates, even of formic acid, which could not be obtained by methods previously mentioned, have been prepared in this way.

* Compare the formation of $\left(\mathrm{H}_{3} \mathrm{CCHCl}\right)_{2} \mathrm{O}$ from acetaldehyde and $\mathrm{HCl}$. L. Brandsma and J. F. Arens. Rec. Trav. Chim. 81, 33 (1962). 
The procedure was also tried with ketone acetals, but in this case only starting compounds and orthoformates could be isolated leaving a polymeric residue. It seems that compounds like $\mathrm{R}_{2} \mathrm{C}\left(\mathrm{OR}^{2}\right) \mathrm{OCOR}^{1}$ in which both R-residues are alkyl groups or one of them is an aryl and the other is an alkyl group decompose in another way thus:

$$
\left(\mathrm{CH}_{3}\right)_{2} \mathrm{C}\left(\mathrm{OR}^{2}\right) \mathrm{OCOR}^{1} \rightarrow \mathrm{CH}_{2}=\mathrm{C}\left(\mathrm{OR}^{2}\right) \mathrm{CH}_{3}+\mathrm{R}^{1} \mathrm{COOH}
$$

followed by acid-catalysed polymerisation of the vinyl ether. Similar observations were made by Lawesson ${ }^{5}$.

c. Other 1-alkoxyalkyl carboxylates can be obtained by distillation of 1 -alkoxyalkyl acetates with acids of higher boiling point than acetic acid when exchange of the acetate residue takes place.

\section{$\mathrm{RCH}\left(\mathrm{OR}^{2}\right) \mathrm{OCOCH}_{3}+\mathrm{R}^{1} \mathrm{COOH} \rightleftarrows \mathrm{RCH}\left(\mathrm{OR}^{2}\right) \mathrm{OCOR}^{1}+\mathrm{CH}_{3} \mathrm{COOH}$}

Because benzoates decompose at about $100^{\circ}$ into aldehyde and ester, the reactive benzoates were prepared by distillation under reduced pressure $(15 \mathrm{~mm})$ in the presence of xylene to restrict the vesseltemperature to $90^{\circ}$. Formates could be obtained by such exchange reactions from butyrates or valerates and the high boiling azeotrope triethylammonium formate/formic acid $^{8}$.

\section{Experimental part}

(With the technical assistance of Miss F. Janssen).

All compounds (see Table II) synthesized, were isolated by distillation, using a $750 \times 12$ mm Vigreux column. Alkoxyalkyl formates obtained in this way (methods 2 and 4) contain $10-20 \%$ of acetals, but complete purification is possible by distillation using a spinningband with at least 25 plates.

Products were identified by NMR spectra, recorded with a Varian HA- 60 spectrometer (pure compounds) or a HA-100 spectrometer (10\% solutions in carbon tetrachloride). TMS was used as an internal standard. $-\mathrm{OCH}_{2}$-protons in alkoxy groups of alkoxyalkyl carboxylates show the same type of splitting as found for diethyl acetals and other compounds with unequivalent methylene protons ${ }^{9}{ }^{10}$.

\section{1-Acetoxyalkyldiethyl orthoformates (I)}

A mixture of equimolar amounts of the appropriate aldehyde and dialkoxymethyl acetate $^{7}$ was left at room temperature for $24 \mathrm{~h}$ and then distilled under reduced pressure. The

\footnotetext{
* J. Poziomek and M. D. Pankau, J. Chem. Eng. Data 8, 627 (1963).

9 J. G. Pritchard and P. C. Lanterbur, J. Am. Chem. Soc. 83, 2105 (1961).

10 J. S. Waugh and F. A. Cotton, J. Phys. Chem. 65, 562 (1961).
} 
Table II.

1-Alkoxyalkyl carboxylates $\mathrm{RCH}\left(\mathrm{OR}^{2}\right) \mathrm{OCOR}^{1}$

\begin{tabular}{|c|c|c|c|c|c|c|c|c|}
\hline $\mathbf{R}$ & $\mathbf{R}^{1}$ & $\mathbf{R}^{2}$ & B.p. ${ }^{\circ} \mathrm{C}$ & $n_{\mathrm{D}}{ }^{20}$ & $\delta$ & $\begin{array}{c}\mathrm{CCl}_{4} \text { or } \\
\text { pure }\end{array}$ & Yield & Method \\
\hline methyl & methyl & ethyl & $49 / 48 \mathrm{~mm}$ & & $\begin{array}{l}5.78 \\
5.91\end{array}$ & $\begin{array}{l}\mathrm{CCl}_{4} \\
\text { pure }\end{array}$ & $65 \%$ & 2 \\
\hline methyl & methyl & n-butyl & $69 / 17 \mathrm{~mm}$ & 1.4030 & 5.83 & pure & $70 \%$ & 2 \\
\hline methyl & methyl & cyclohexyl & $95 / 14 \mathrm{~mm}$ & 1.4359 & 5.97 & pure & $75 \%$ & 2 \\
\hline methyl & $n$-pentyl & isobutyl & $134 / 12 \mathrm{~mm}$ & 1.4199 & & $\mathrm{CCl}_{4}$ & $60 \%$ & 2 \\
\hline methyl & phenyl & ethyl & $76-78 / 0.8 \mathrm{~mm}$ & 1.4925 & 6.08 & $\mathrm{CCl}_{4}$ & $55 \%$ & 5 \\
\hline ethyl & $\mathrm{H}$ & ethyl & $38 / 15 \mathrm{~mm}$ & 1.3952 & 5.87 & pure & $\begin{array}{l}35 \% \\
55 \%\end{array}$ & $\begin{array}{l}2 \\
5\end{array}$ \\
\hline ethyl & $\mathrm{H}$ & $n$-butyl & $60 / 13 \mathrm{~mm}$ & & 5.80 & $\mathrm{CCl}_{4}$ & $65 \%$ & 5 \\
\hline ethyl & methyl & ethyl & $45 / 14 \mathrm{~mm}$ & 1.3965 & 5.82 & pure & $55 \%$ & 2 \\
\hline ethyl & $n$-propyl & n-butyl & $98-100 / 13 \mathrm{~mm}$ & & 5.40 & $\mathrm{CCl}_{4}$ & $40 \%$ & 3 \\
\hline ethyl & $n$-butyl & ethyl & $85 / 14 \mathrm{~mm}$ & 1.4100 & 5.77 & pure & $90 \%$ & 5 \\
\hline$n$-propyl & $\mathrm{H}$ & methyl & $38 / 13 \mathrm{~mm}$ & 1.3937 & 5.76 & $\mathrm{CCl}_{4}$ & $34 \%$ & 3 \\
\hline$n$-propyl & $\mathbf{H}$ & ethyl & $46-47 / 13 \mathrm{~mm}$ & 1.4000 & 5.86 & $\mathrm{CCl}_{4}$ & $\begin{array}{l}40 \% \\
60 \%\end{array}$ & $\begin{array}{l}2 \\
5\end{array}$ \\
\hline$n$-propyl & methyl & methyl & $55 / 17 \mathrm{~mm}$ & 1.3930 & 5.72 & pure & $30 \%$ & 3 \\
\hline n-propyl & methyl & ethyl & $62 / 17 \mathrm{~mm}$ & 1.4020 & $\begin{array}{l}5.82 \\
5.70\end{array}$ & $\begin{array}{l}\text { pure } \\
\mathrm{CCl}_{4}\end{array}$ & $68 \%$ & 2 \\
\hline$n$-propyl & ethyl & methyl & $64 / 15 \mathrm{~mm}$ & & 5.65 & $\mathrm{CCl}_{4}$ & $35 \%$ & 3 \\
\hline$n$-propyl & ethyl & ethyl & $76 / 15 \mathrm{~mm}$ & 1.4058 & 5.65 & $\mathrm{CCl}_{4}$ & $32 \%$ & 3 \\
\hline$n$-propyl & $n$-propyl & methyl & $75 / 13 \mathrm{~mm}$ & & 5.70 & $\mathrm{CCl}_{4}$ & $35 \%$ & 3 \\
\hline$n$-propyl & $n$-propyl & ethyl & $83 / 13 \mathrm{~mm}$ & 1.4105 & 5.70 & $\mathrm{CCl}_{4}$ & $40 \%$ & 3 \\
\hline n-propyl & isopropyl & ethyl & $85 / 19 \mathrm{~mm}$ & & 5.65 & & $90 \%$ & 5 \\
\hline n-propyl & phenyl & ethyl & $82-84 / 0.4 \mathrm{~mm}$ & & 5.84 & $\mathrm{CCl}_{4}$ & $55 \%$ & 5 \\
\hline isopropyl & $\mathbf{H}$ & ethyl & $50 / 18 \mathrm{~mm}$ & & 5.73 & pure & $50 \%$ & 2 \\
\hline isopropyl & methyl & ethyl & $57 / 20 \mathrm{~mm}$ & 1.3998 & & pure & $60 \%$ & 2 \\
\hline$t$-butyl & methyl & ethyl & $54 / 15 \mathrm{~mm}$ & 1.4019 & 5.40 & $\mathrm{CCl}_{4}$ & $40 \%$ & 2 \\
\hline$n$-hexyl & $\mathbf{H}$ & ethyl & $96 / 15 \mathrm{~mm}$ & & 5.90 & pure & $35 \%$ & 2 \\
\hline phenyl & $\mathrm{H}$ & ethyl & $120 / 18 \mathrm{~mm}$ & & 6.96 & pure & $60 \%$ & 4 \\
\hline phenyl & methyl & ethyl & $121 / 12 \mathrm{~mm}$ & & 6.80 & pure & $65 \%$ & 4 \\
\hline
\end{tabular}

1-ethoxyethyl acetate ${ }^{11} 125-130^{\circ}$

1- $n$-butoxyethyl acetate $69.5-70^{\circ} / 21 \mathrm{~mm}, n_{\mathrm{D}}{ }^{20}=1.4031$

1-ethoxy-n-propyl acetate $46.3-46.8 \% 14 \mathrm{~mm}, n_{\mathrm{D}}{ }^{20}=1.3970$

1-ethoxy-n-butyl acetate $53-54^{\circ} / 10 \mathrm{~mm}, n_{\mathrm{D}}{ }^{20}=1.4020$

1-ethoxy- $n$-butyl propionate $66-67^{\circ} / 10 \mathrm{~mm}, n_{\mathrm{D}}{ }^{20}=1.4070$

1-ethoxybenzyl acetate ${ }^{11} 243-245^{\circ}$

${ }^{11}$ L. Claisen, Ber. 31, 1018 (1898). 
following compounds were isolated from the respective equilibrium mixtures in yields of about $5 \%$.

$\mathrm{CH}_{3} \mathrm{CH}\left(\mathrm{OCOCH}_{3}\right) \mathrm{OCH}\left(\mathrm{OCH}_{3}\right)_{2}$, b.p. $67 \% 17 \mathrm{~mm}, \delta \mathrm{HC}(-\mathrm{O}-)_{3} 5.23$ (pure).

$\mathrm{CH}_{3} \mathrm{CH}\left(\mathrm{OCOCH}_{3}\right) \mathrm{OCH}\left(\mathrm{OC}_{2} \mathrm{H}_{5}\right)_{2}$, b.p. $67^{\circ} / 0.5 \mathrm{~mm}, \delta \mathrm{HC}(-\mathrm{O}-)_{3} 5.33$ (pure).

$\mathrm{C}_{2} \mathrm{H}_{5} \mathrm{CH}\left(\mathrm{OCOCH}_{3}\right) \mathrm{OCH}\left(\mathrm{OCH}_{3}\right)_{2}$, b.p. $82^{\circ} / 17 \mathrm{~mm}, \delta \mathrm{HC}(-\mathrm{O}-)_{3} 5.23$ (pure).

\section{1-Alkoxyalkyl carboxylates from aldehydes, carboxylic acids and dialkoxymethyl carboxylates}

Equimolar amounts of the three starting compounds were mixed and left at room temperature for at least $24 \mathrm{~h}$ ( $72 \mathrm{~h}$ for pivalic aldehyde) and then distilled under reduced pressure. On further distillation after the isolation of the product, acylals and compounds which (according to NMR and mass spectra) are probably $\left(\mathrm{RCHOCOR}^{1}\right)_{2} \mathrm{O}$ could be obtained.

$$
\begin{aligned}
& \text { e.g., acylals, } \mathrm{RCH}\left(\mathrm{OCOCH}_{3}\right)_{2} \mathrm{R}=\mathrm{CH}_{3}, \quad \text { b.p. } 65-67^{\circ} / 13 \mathrm{~mm} \\
& \mathrm{R}=\mathrm{C}_{2} \mathrm{H}_{5}, \quad \text { b.p. } 78 \% 13 \mathrm{~mm} \\
& \mathrm{~K}=n-\mathrm{C}_{3} \mathrm{H}_{7} \text {, b.p. } 52 \% 1.5 \mathrm{~mm} \\
& (\mathrm{RCHOCOCH})_{2} \mathrm{OR}=\mathrm{CH}_{3} \text {, b.p. } 84 \% 13 \mathrm{~mm} \\
& \mathrm{R}=\mathrm{C}_{2} \mathrm{H}_{5}, \quad \text { b.p. } 113 \% 13 \mathrm{~mm} \\
& \mathrm{R}=\mathrm{C}_{3} \mathrm{H}_{7}, \quad \text { b.p. } 84-86^{\circ} / 15 \mathrm{~mm}
\end{aligned}
$$

Shortening of the reaction time by raising the temperature $\left(e . g ., 5 \mathrm{~h}\right.$ at $\left.90^{\circ}\right)$ led to lower yields for the lower aldehyde homologues. Only in the synethesis of formates was the mixture kept at $80^{\circ}$ for $5 \mathrm{~h}$, but then only a few drops of formic acid were used.

The method fails with benzaldehyde and ketones.

\section{1-Alkoxyalkyl carboxylates from acetals and carboxylic acids}

0.2 Mole of an acetal and 0.3 mole of an acid were refluxed for about $4 \mathrm{~h}$ at such pressure $(15-50 \mathrm{~mm})$ that the bottom temperature did not exceed $90^{\circ}\left(50^{\circ}\right.$ in the synthesis of formates). The alcohol was removed as vapour or was allowed to distill off. The products were isolated by distillation. The method fails for diethyl acetals of acetaldehyde, butyraldehyde or benzaldehyde in combination with formic acid.

\section{1-Ethoxybenzyl acetate and formate}

Equimolar amounts of benzaldehyde, diethyl acetal, diethoxymethyl acetate (or formate) and acetic acid (or 0.1 equivalent of formic acid) were kept at room temperature for $5 \mathrm{~h}$ and distilled under reduced pressure (the formate with a spinning band).

\section{1-Alkoxyalkyl carboxylates from corresponding acetates by exchange reactions}

Equimolar amounts of a 1-alkoxyalkyl acetate and a higher boiling carboxylic acid were mixed and acetic acid was distilled off. In the synthesis of benzoates xylene was added before distillation, which was performed at such a pressure that the bottom temperature did not exceed $90^{\circ}$.

Formates were obtained via a similar procedure by distillation of a mixture containing 0.25 mole of an alkoxy-alkyl butyrate, $12 \mathrm{~g}$ of triethylamine and $12 \mathrm{~g}$ of formic acid. 


\section{Experiments with ketones}

Diethyl acetals of acetone, acetophenone, cyclopentanone or cyclohexanone were mixed with equimolar amounts of diethoxymethyl acetate and acetic acid. The mixtures were left at room temperature for at least $12 \mathrm{~h}$. after which time the mixture were dark brown and, in several experiments, dark coloured polymeric products had separated from the solutions. On distillation only starting compounds, ethyl orthoformate and decomposition products were isolated.

\section{Acknowledgement.}

We thank Mr. Smeets and Mrs. M. Hoevenaars for recording the NMR spectra. 